\title{
Institutional Analysis of the System \\ of Public Interactions in the Region's Economy \\ to Provide for the Infrastructure \\ of the Population Living Conditions \\ and Quality of Life
}

\author{
Vladislav N. Rutskiy* \\ Siberian Federal University \\ 79 Svobodny, Krasnoyarsk, 660041, Russia
}

Received 04.11.2016, received in revised form 07.11.2016, accepted 17.11.2016

The article analyzes the institutional system of public interactions of the region's population and state authority and administration bodies as the system of provision of infrastructure for population living conditions in the course of the qualitative growth of economy. The study uses a method of the economic analysis of regulations as one of the main research tools that is modified on the basis of combination of the neo-institutional and system-reproduction approaches. The author reveals trends of the corresponding institutional changes in the system of public interactions in the region's economy by the example of a number of primary infrastructure sectors of the Krasnoyarsk Territory (Krai), namely the transport and urban construction complexes. The author also proposes necessary directions of the relevant public institutional development in the region.

Keywords: system of public interactions in the economy, infrastructure for population living conditions, infrastructural goods, qualitative economic growth, economic analysis of regulations, institutional analysis.

The article was written with the support of KSAU "Krasnoyarsk Regional Fund of Support for Scientific and Technical Activities" as a part of the grant awarded by Siberian Federal University in 2016 on the topic: "Methodological approaches to the assessment and development of the structural policy of reproduction of the human capital for the sustainable development strategy of the Krasnoyarsk Krai in terms of diversification and technological modernization of the economy".

DOI: 10.17516/1997-1370-2016-9-11-2640-2652.

Research area: economics, culture studies.

\section{Introduction}

The main element of improving the quality of life and human potential in the regional economy is the public system to provide appropriate services to the population, which in the narrow sense means a system of regulatory public services, and in a broader sense - the formation of a specific environment of the infrastructure

(C) Siberian Federal University. All rights reserved

* Corresponding author E-mail address: rootskey.vn@gmail.com 
of the population living conditions in the region. The system of relations of the actors in the infrastructure of the population living conditions includes functionally related sustainable strategies of behaviour of the producers of infrastructural goods and the providers of necessary resources, their consumers, concerned public organizations and bodies of the state authority and local self-administration. At the same time, the simultaneous involvement and active participation in the infrastructure reproduction on the part of its actors creates the need for the institutional measurement of their interactions.

\section{Conceptual framework of the study}

The system of public interactions to provide for the development of the infrastructure of the population living conditions necessarily reflects the complexity of the reproduction processes in the infrastructure of living conditions at the junction of the basic (specializing) and derivative (supporting the basic) sectors of the integrated economy. In our view, solution of a large part of problems faced in the implementation of the infrastructure potential lies in the plane of the institutional environment and appropriate institutional changes. Here are some considerations that confirm these assumptions.

Firstly, relations of the infrastructure actors cannot be fully regulated by any single group of institutions (e.g. market or planned) and depend on a particular situation of production, distribution or consumption of infrastructural goods by groups of economic, social and public actors in sectoral and territorial aspects of their interaction. The analysis of such relations requires building a hierarchical structure of norms and institutions ${ }^{1,2,3}$.

Secondly, the content of the basic elements of the infrastructure institutions (routines ${ }^{4}, 5$ and norms formed from them) is determined by the mutual influence of rational and societal determinants of relations of the actors in the infrastructure of living conditions ${ }^{6}$.

Thirdly, the basis of institutions as the restrictive or stimulating rules of behaviour of individuals involves not only routines that have become rules, but also the associated mechanisms of coercion of the guarantors to execute rules by using incentives and penalties. Therefore, another important part of the institutional analysis of the infrastructure of living conditions is a set of coordination mechanisms ${ }^{8}$ combining elements of five basic forms - "market", "hierarchy", "relationship contracting", "common cause" and "community".

These forms are distinct in the alternative values of institutional characteristics that centralize or decentralize the relationships of the actors in different situations and with different efficiency ${ }^{9,10}$. Using the same coordination forms in some cases increases, and in others - reduces the efficiency of reproduction of the human and infrastructural capital, which leads to a variety of coordination forms ${ }^{11,12}$.

Fourthly, the institutional changes in the infrastructure are derived from social and technological changes with incomplete information about the future ${ }^{13,14}$. They are carried out by determining the most probable and possible alternatives to borrowing, spontaneous invention and conscious design of rules and institutions, which can occur on the basis of mechanisms of the political or institutional market ${ }^{15,16}$.

\section{Problem statement}

The mechanism of public interactions of the population and the bodies of authority as a mechanism of institutional changes in the infrastructure of the population living conditions, in which the central place is taken by the appropriate institutional development projects, can be illustrated by using a scheme of 
reproduction of a social product of the regional economy in a model of its qualitative economic growth (see Figure 1).

As it can be seen, the main result of functioning of the infrastructure of the population's living conditions in the region as a specific sphere of regional economy at the junction of the basic (specializing) and derivative (supporting) sectors is the reproduction of the human capital (mainly for the needs of basic sectors) and the infrastructural capital (mainly for the needs of derivative sectors). In this case it is the development of infrastructure of living conditions that can lead to the simultaneous qualitative shifts in the sources, the mechanism and the results of the economic growth. It is great performance of the infrastructure of living conditions in terms of production of the infrastructure and human capital that will mean strengthening of competitive opportunities for all economic actors, which will result in the possibility to derive new benefits from the region's interaction with the external environment (external economic systems and the natural environment).

The infrastructure of the population living conditions and the corresponding system of public relations and public authorities in the region show a number of features that determine particular importance of the institutional aspects of the relations of its actors ${ }^{17}$ :

- an all-pervading nature (functioning in the territorial and functional context at the junction of the basic and derivative sectors, focus on reproduction);

- a system of infrastructural goods that, to a greater or lesser degree, are public and created in the primary (tangible conditions of the capital reproduction), secondary (goods mediating the social product flow) and tertiary sectors (pure public goods) suggesting the need for consistent regulation of the infrastructure in the political and institutional markets;
- fundamental trinity of relationships on the reproduction of infrastructural benefits that are emerging between economic, social and public entities of the integrated economy dictating the need to use coordination different mechanisms with the formation of private preferences into public ones;

- risks of loss of economic efficiency at the production of infrastructure goods that require both market and non-market methods of financing and mutual control of production by economic, social, and public entities.

Therefore, the purpose of the infrastructure for population living conditions is to create synergetic (e.g. multiplicative) effects in the economy by reducing the total social costs of production (the contribution of human and infrastructure capital of the economy) at the same or greater value of the public product production.

The above considerations clearly show that the study of the institutional system of public interactions ensuring the reproduction of the infrastructure for the population living conditions can be made on the basis of a systematic approach by analyzing the rules and institutions, evaluating their feasibility and efficiency, identifying trends in institutional change.

\section{Research methods}

It is well-known that the institutional approach to the economic analysis of regulations lies within the framework of the economic theory of law, which is the basis for a whole field of interdisciplinary research - economic analysis of law ${ }^{18,19,20}$. The essence of this analysis is to assess the existing or planned regulations in terms of benefits and costs they entail in the case of actual or projected performance of regulations on the part of recipients and guarantors. In order to identify the components of the institution as the existing rule, we use the corresponding logic pattern containing a set of elements: the 


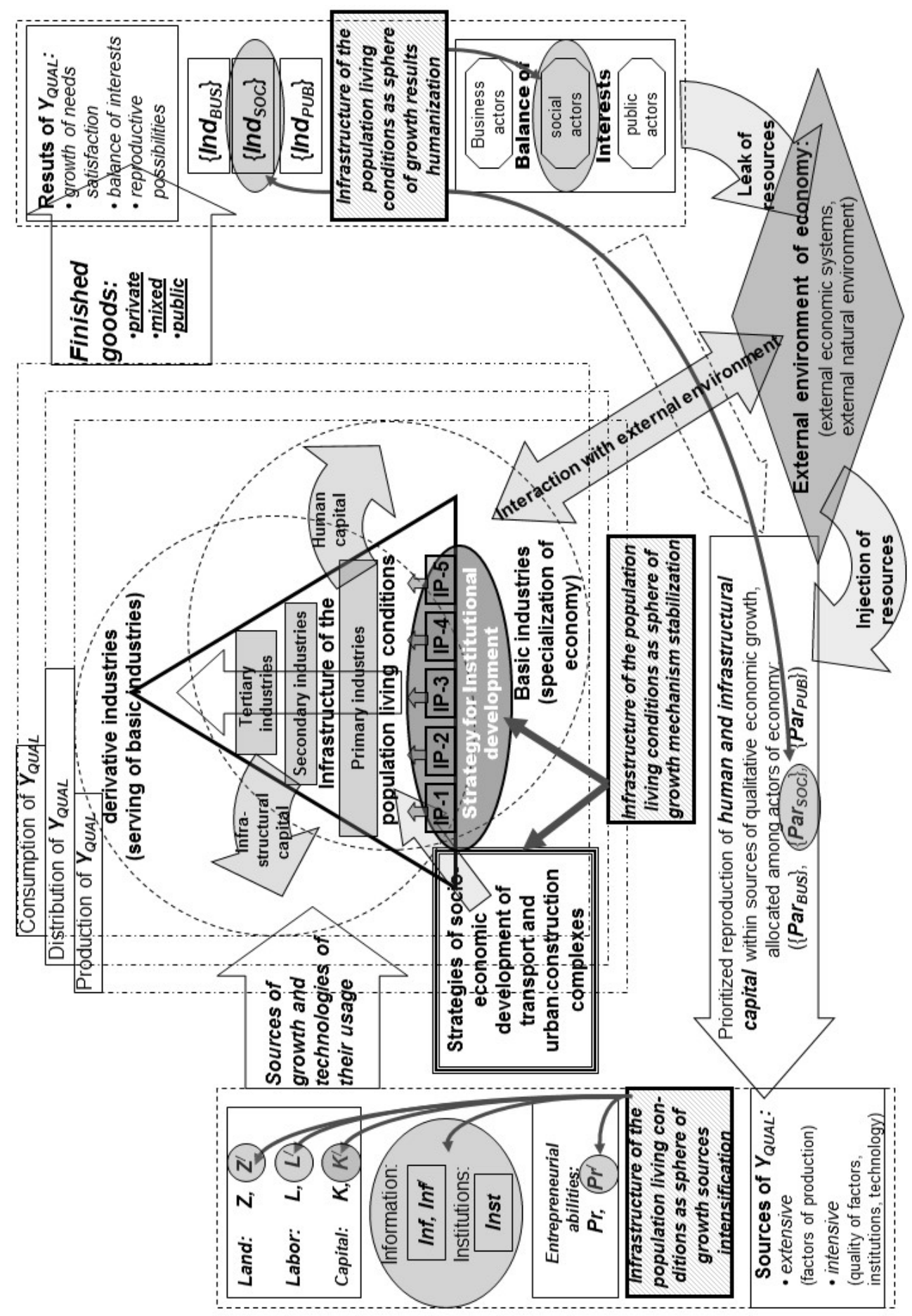

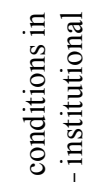
, 号

苛

芒

궁

苟

$\stackrel{\Xi}{\Xi}$

亲

.

近

్ㅡㅇ

플

吾

范

.

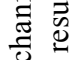

로

范

s)

:

壳

$\vec{z}$

。ี

흘.

客:

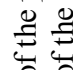

氜

옹

. .

응

ह

능

疍

突

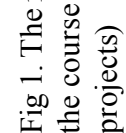


prescribed actions (rules), conditions for the rules application, the recipient, sanctions, the guarantor of the implementation of the rules, the mechanism for enforcement to perform the actions ${ }^{21,22}$.

The economic analysis of the regulations is performed in two areas ${ }^{23}$ :

1) efficiency implying the comparison of costs and benefits for recipients and guarantors of the rules of the institution, in comparison with the situation of an alternative institution or the situation of its absence;

2) feasibility implying certain institutional components, societal acceptability of the institutions and their constituent regulations their compliance with the interests and culture of particular interest groups, as well as the availability of finances, information, time and other resources of recipients and guarantors, which are required for the successful implementation of the regulations.

Let us note that the costs can be both transformational and transactional. Benefits can also be direct (compensation for the goods sold) and indirect (saving of transformational or transactional costs).

In accordance with the modern neoinstitutional theory, the object of the analysis of any sphere of economic relations can be four types of institutions:

- formal institutions regulating the relations of an indefinite group of entities (legislative and non-legislative acts);

- formal institutions regulating the relations of a certain group of actors (components of specific contracts, formal organizations with the known composition, etc.);

- informal institutions regulating the relationships of a certain group of actors (informal organizations and associations, etc.);

- informal institutions regulating the relationships of an indefinite group of actors (traditions, habits, etc.).
None of these types exists in isolation from each other, but is subject to the logic of the institutional organization of economic order implying the ability of institutions to replace and complement each other. The base is formed by the formal institutions for an indefinite actors - regulatory acts of legislative (self) and nonlegislative (subordinate) type, which provide the basic rules in regulated areas and levels of economic relations with the predominance of rational motives of the decisions taken by the actors. The relevant rules form the basis of the institutional order of the economic system. This is followed by formal institutions for certain groups of actors which, on the one hand, are meant to follow the actors of institutions of the first type, but on the other hand, specify the relationships for the sake of reducing the uncertainty of future costs and benefits. Even more peculiar are the institutional components of informal institutions for certain groups of actors, in which societal (corresponding to the culture) factors already begin to play a more important role. Institutional components for informal institutions, for indefinite groups of actors, in which the societal relations are the most powerful factors flowing directly into the culture of actors and noneconomic spheres of relations are understood widely, but vaguely.

The study of any institutional structure should be a simulation of the hierarchy of regulations and institutions, finding out how the constituting and derivative rules and institutions fit together, how the rules and institutions relate to each other and how effective they are, what are the mechanisms for enforcement of the rules.

In order to form an input for the analysis of specific institutions governing the reproduction of primary infrastructure benefits, in our view, it is appropriate to supplement the neo-institutional approach, which allows to describe institutions as the balance between private transactions ${ }^{24}$, with 
a system-integrated approach to reproductive economy. The combination of these approaches allows to develop a special algorithm for the institutional analysis of the infrastructure. It involves the separation of types (special interest groups involved in the reproduction of goods and related to manufacturers, consumers and regulators), objects (goods to be exchanged during the transactions with producers, consumers, regulators), objects of the relations (transactions with the goods, the stage of its reproduction). Then it is noteworthy to describe institutes defining transactions, in accordance with the known logic pattern. It will allow to evaluate the success of transactions in accordance with the applied institutions (the benefits and costs of their implementation, their relationship).

The possibilities of the economic analysis of regulations as a tool to study the institutional system of public interactions in the economy of the region have been implemented on the example of the Krasnoyarsk Krai, which is characterized by a number of specific trends in the infrastructure development concerning living conditions of the region's population, while the region has a significant natural resource potential, extensive growth of basic raw material exportoriented industries. At the same time the region is characterized by underdeveloped secondary industries, a strong differentiation of socioeconomic indicators of industries and territories, a high dependence on the external environment and the imbalance in the structure of consumption and accumulation ${ }^{25,26}$.

The study included the systematization of formal rules and institutional arrangements regarding production, distribution and consumption of corresponding infrastructure goods. The institutes of Krasnoyarsk Krai's infrastructure sectors were economically analyzed within the primary sectors of the living conditions infrastructure: transport and urban construction, including residential construction, housing and utilities infrastructure ${ }^{27}$. These fields have a significant part of typical institutional problems $^{28}$.

All the actors of the integrated regional economy (economic, social, public) play certain roles (producers, consumers and regulators) in the reproduction of infrastructural benefits that applies equally to primary, secondary and tertiary sectors of the infrastructure of population living conditions ${ }^{29}$. At the same time, the role of consumers is partially played by social actors (households). Manufacturers supplying ready-made infrastructure goods and their intermediate components are represented by economic and public entities (private, state and municipal enterprises and state and local government institutions). Regulators are mainly public entities (state government and local selfgovernment authorities), but can also be social actors (civil society organizations).

Basing on these roles, we can talk about the possible existence of seven types of cross-type relationships and related transactions' objects. As the analysis shows the relations between the actors are actually represented in most areas of reproduction of the infrastructure goods: producers-consumers, regulators- manufacturers, consumers-consumers, consumers-regulators, regulators-regulators, producers-regulators. The sphere of relations "producers-producers" is not regulated by applicable legislative acts. Actors nominally combined by roles represent special interest groups (SIG).

Legislative acts governing the transport infrastructure of the transport complex, are mainly aimed at regulating the produced, distributed and consumed goods. The produced goods include: civil aviation services, freight transportation, aviation security. The distributed goods include: issuance of state duties, licenses, certificates of compliance, budget allocations; 
social support. The consumed goods include: services of purchasing tickets, transportation of baggage, cargo and passengers; the use of vehicles. We have studied 49 legislative acts (when the number of rules is 444) regulating relations in the sphere of transport services in the region with the total number of connections between the acts -75 .

It was determined that in the field of transport services, namely, the considered legislative acts do not always include the sanctions applied in the event of failure of the rule. The content of the rules is relatively certain (almost in $100 \%$ of cases), at the same time, the conditions of application of the rules are defined in less than $30 \%$ of cases. The efficiency and feasibility of the legislative acts governing the relations of the actors in the transport complex of the region are not sufficient for high-quality reproduction of the relevant infrastructure goods, because a significant part of special interest groups is weakly (not more than in $30 \%$ of cases) involved in regulated relations. On the other hand, in all areas of relations, most of the institutional components are weakly (not more than in $30 \%$ of cases) or medium (from 30 to $70 \%$ of cases) defined, and medium (from 30 to $70 \%$ of cases) defined at the level of infrastructure actors' roles. In this regard, it is quite difficult to calculate costs and benefits connected with the application of legislative acts for specific areas of relations.

Legislative acts in the sphere of housing and utilities regulate the following types of goods: produced and distributed. The produced goods include utility services, water supply and sewage, removal of solid and liquid waste, gas supply, heating, electric power supply. The distributed goods include subsidies for the development of design documentation and construction of solid waste landfills, for reimbursement of the costs of capital repairs of apartment houses and repair of yards, subsidies for housing and utilities, as well as additional measures of social support for housing and utilities services.

We have studied 57 (when the number of rules is 564) of legislative acts regulating relations in the sphere of housing and utilities services of the region with the total number of connections between the acts -65 . The analysis of the legislative acts in the sphere of housing and utilities services allows to conclude that the sanctions applied in case of non-fulfilment of the prescribed actions, are not clearly determined in most cases. Guarantors in the sphere of housing and utilities services in all areas of relations in $100 \%$ of cases are the regulators (all levels of government or their authorized agencies). The content of the rules is relatively certain (almost in $100 \%$ of cases) in all aspects of the relationships of housing and utilities services. However, the definition of the conditions for the application of rules and sanctions governing the production and distribution of benefits in all spheres of relations is extremely low (less than in $30 \%$ of cases). Interests of the consumers are hardly taken into account in the rules governing the production of services in utilities, maintenance and repair of the property of homeowners. The same applies to the rules governing the allocation of financial resources, including subsidies for the reimbursement of costs to organizations engaged in complete repair, service in energy supply and elevators. At the same time, the interests of producers and regulators for all types of services are considered at the medium level (from 30 to $70 \%$ of cases). It is noteworthy that in the rules governing the allocation of financial resources in the form of subsidies for social support of the population, the interests of the executive bodies are considered at the medium level, and the interests of the population as the recipient of subsidies are practically not taken into account.

The analysis showed that the efficiency and feasibility of legislative acts regulating the 
relations of the actors in the sectors of housing and utilities in the Krasnoyarsk Krai's urban complex are not sufficient for high-quality reproduction of the relevant infrastructure goods, because a significant part of special interest groups is not involved in the regulated relations. On the other hand, in all spheres of relations, most institutional components and the role of the actors are determined at the medium level resulting in difficulties with calculation of costs and benefits from the use of legislative acts in specific areas of relations.

Legislative acts in the field of construction and repair of housing regulate the following types of goods: produced, consumed and distributed. The produced goods include: design of buildings and structures on the basis of safety requirements; construction, reconstruction and repair of buildings and structures; development of the instructions for the operation of an apartment building; engineering survey works; technical conditions, connection of the capital construction object to the engineering network; territorial planning; reorganization and rearrangement of the dwelling; development of regional standards for urban design; cadastral work. The consumed goods include: the use and maintenance of premises for personal needs of accommodation. The distributed goods include: subsidies for major repair of common property of the owners of premises, entrances to apartment buildings, and repair itself; investment projects; the provision of premises of the regional housing stock; social payments for the purchase or construction of housing for young families; provision of the service premises; social payments for the purchase (construction) of housing to the participants of the target programmes, including veterans; financial assistance for the construction (purchase) of individual houses; equity financing of major repair of apartment houses; subsidies for major repair of engineering infrastructure; privatization of housing stock.

We have studied 60 (when the number of rules is 1,302) of the legislative acts regulating relations in the sphere of housing and utilities services of the region with the total number of connections between acts -85 . The analysis of the legislative acts in the sphere of construction and repair of housing allows to conclude that the sanctions applied in case of non-fulfilment of the prescribed actions, are not clearly determined in most cases. The guarantors in the field of construction and repair of housing in all areas of relations in $100 \%$ of cases are the regulators of goods reproduction. In most areas of relations, the sanctions have a rather vague nature. The content of the rules is relatively certain (almost in $100 \%$ of cases) in all aspects of the relationships of construction and repair of housing. However, the definition of the conditions for the application of rules and sanctions governing the production and distribution of benefits in all spheres of relations is extremely low (less than in $30 \%$ of cases). The rules practically do not consider the interests of producers and consumers of goods, except for controlling the distribution of financial resources and social support of the population (from 30 to $70 \%$ of cases). However, the interests of regulators are considered at the level above average (from 70 to $100 \%$ of cases).

Therefore, it can be argued that the efficiency and feasibility of legislative acts regulating the relations of the actors in the sectors of construction and repair of housing Krasnoyarsk Krai's urban complex are not sufficient for high-quality reproduction of the relevant infrastructure goods, because a significant part of special interest groups is weakly or medium-level involved in the regulated relations. In all spheres of relations the roles of infrastructure entities are weakly 
and medium-level determined, but most institutional components are determined at the medium or high level, which to some extent facilitates the calculation of costs and benefits from the use of legislative acts in specific areas of relations.

\section{Discussion}

The analysis of the institutional components and the relationships between these components revealed a lot of institutional problems present at all levels of the relations between producers, consumers and regulators in the operation of the primary sectors of the infrastructure of population living conditions in the Krasnoyarsk Krai as the institutional system of public interactions. This includes the mechanisms of decision-making on the formation of the solvent demand for infrastructure goods, actions for the implementation of these decisions, as well as for the regulation of the activities of organizations producing and distributing goods.

The most relevant, in our opinion, is the problem of fuzzy specification of institutional components for specific types of relations between the actors, weak incentives for participation of the population in developing public preferences about the reproduction of infrastructural benefits, as well as the weak legal status and incentives for the relevant public and self-regulatory organizations to participate in the formation and implementation of the state and municipal policy.

It can be argued that the problems defined in the course of analysis of the institutional environment of the transport and urban infrastructure of the population living conditions are institutional traps. A lot of "white spots" and "gaps" in legislation perpetuates the system of informal institutes for specified or unspecified participants, on the other hand, the absence of the aggregate demand for institutional change from consumers and producers of infrastructural benefits at the political markets provokes decision-making at the institutional markets and establishment of inefficient institutes.

To solve the identified problems the following strategic trends are most relevant in the institutional development of the system of public interactions providing the reproduction of the infrastructure of the Krasnoyarsk Krai population living conditions:

1. Increasing public satisfaction with the scope and quality of the relevant infrastructure benefits (goods and services).

2. Strengthening of monitoring theactivities of public organizations and self-regulatory organizations, manufacturers on the part of the population and producers, respectively.

3. Increasing the involvement of public and self-regulatory organizations in the formation and implementation of state and municipal policy in the field of regulation of the population's life infrastructure.

4. Improving the interaction between producers of infrastructure benefits with public and self-regulatory organizations, governing authorities of the state level and local government.

5. Improving the efficiency of the resource use in production and distribution of appropriate infrastructure benefits while increasing local, regional and national competitiveness of organizations producing and distributing benefits at the respective markets.

There can be various initiatives for implementation of these strategies for the development of institutional infrastructure of the population living conditions in the form of institutional projects. These projects should be aimed at a more precise specification of the reproduction relations (types of entities, goods subject to transactions, actions with goods as the object of transactions) and institutional components (content of the rules, conditions of 
their application, recipients, guarantors, sanctions, enforcement mechanisms for the execution of the rules). Such projects can be:

- Improvement of existing and creation of new performance standards (e.g. standards of public and municipal services) for companies producing and distributing infrastructure goods;

- Establishment of special organizational structures (engineering, design, holding, etc.), for specific tasks of infrastructure development designed to be a more effective form of coordination of specific types of relationships;

- Introduction of the system of sanctions and incentives for the relevant existing and new special interest groups;

- Formal assigning of control and supervision functions in terms of production and distribution of infrastructure benefits to special interest groups, members of public and self-regulatory organizations, as well as stimulating these functions by the state and local governments.

\section{Conclusion}

Thus, finding a way out from the institutional traps requires accumulation of flexible solvent demand for institutional changes, effective from the point of view of the reproduction of the human and infrastructure capital of the economy as a whole. Major carriers of such demand should become consumers of infrastructural benefits potentially interested in improving the quality of life and human capital formation, the producers of these goods including private, state and municipal organizations (companies and institutions), which may compete with each other at the expense of productive infrastructure capital. The set of institutional projects implemented on the basis of the balance of interests of these special interest groups must be subordinated to the achievement of the main goal of transformation of reproductive relations in the infrastructure of the living conditions for the region's population for a more complete disclosure of its potential in order to reproduce the human and infrastructure capital.

1 Vol'chik, V.V. (2009). Komplementarnost' $i$ ierarkhiia institutov v ramkakh khoziaistvennogo poriadka [Complementarity and hierarchy of institutions within the economic order]. Scientific works of Donetsk National Technical University, Series: Economics, 37-1, 35-41.

2 Levin, S.N. (2007). Formirovanie konstitutsionnykh pravil v ekonomike Rossii [Formation of the constitutional rules in the Russian economy]. Kemerovo, Kuzbassvuzizdat, 263 p.

3 Kleiner, G.B. (2004). Evoliutsiia institutsional'nykh system [The evolution of the institutional systems]. Moscow, Nauka, $240 \mathrm{p}$.

4 Nelson, R.R., Winter, S.J. (2002). Evoliutsionnaia teoriia ekonomicheskikh izmenenii [Evolutionary Theory of Economic Change]. Moscow, Delo, 536 p, 142.

5 Hodgson, G.M. (2003). Ekonomicheskaia teoriia i instituty: manifest sovremennoi institutsional'noi ekonomicheskoi teorii [Economic Theory and Institutions: a manifesto for a modern institutional economics], Moscow, Delo. 464 p, 202.

6 Kirdina, S.G. (2000). Institutsional'nye matritsy i razvitie Rossii [The institutional matrices and the development of Russia], Moscow: TEIS, $213 \mathrm{p}$.

7 Polterovich, V.M. (2007). Elementy teorii reform [Elements of the reform theory]. Moscow, ZAO Publishing House Ekonomika, 447 p, 87-130.

8 Hayek, F.A. (1992). Pagubnaia samonadeiannost'. Oshibki sotsializma [The Fatal Conceit: The Errors of Socialism], Moscow, Publishing House Novosti, 304 p.

9 Commons, J.R. (1931). Institutional economics, In American Economic Review, 21, 648-657.

10 Eggertsson, T. (2001). Ekonomicheskoe povedenie $i$ instituty [Economic behaviour and institutions], Moscow, Delo, 408 p.

11 Sapir, G.A. (2001). K ekonomicheskoi teorii neodnorodnykh system: opyt issledovaniia detsentralizovannoi ekonomiki [On the economic theory of non-uniform systems: research experience of the decentralized economy], Moscow, Higher School of Economics, 248 p, 171.

12 Simon, H.A. (2000). Teoriia priniatiia reshenii [Theory of decision-making]. In Vekhi ekonomicheskoi mysli. Teoriia firmy [Milestones of economic thought. Theory of the firm], 2. Ed. Gal'perin, V.M., St. Petersburg: School of Economics, 54-72.

13 North, D. (1997). Institutsional'nye izmeneniia: ramki analiza [Institutional Changes: Analysis framework]. In Voprosy ekonomiki [The economy issues]. 3, 6-17.

14 Alchian, A. (1950). Uncertainty, evolution and economic theory, In Journal of political economy, 58(3), 211-221.

15 Pejovich, S. (1996). The market for institution versus the strong hand of the state: the case of Eastern Europe. Economic Institutions, Market and Competition, B. Dallago and L. Mittone (eds), Cheltenham, 111-126. 
16 Tambovtsev, V.L. (2001). Institutsional'nyi rynok kak mekhanizm institutsional'nykh izmenenii [The institutional market as a mechanism for institutional changes]. In Obshchestvennye nauki i sovremennost' [Social Sciences and Modernity], 5, 25-38.

17 Pyzhev, I.S., Rutskii, V.N. (2011). Institutsional'nyi podkhod k issledovaniiu infrastruktury zhiznedeiatel'nosti naseleniia makroekonomicheskogo urovmia [Institutional approach to the study of the infrastructure of the population living conditions at the macroeconomic level]. In Nauchnye trusy DonNTU. Seriia: ekonomicheskaia [Scientific works of Donetsk National Technical University. Series: Economics], 40-2, 232-237.

18 Coase, R. (2007). Firma, rynok i pravo [The Firme, the Market and the Law], Moscow, Novoe izdatel'stvo, 224 p., 22.

19 Posner, R.A. (2004). Ekonomicheskii analiz prava [Economic Analysis of Law], translated from English. Sain Petersburg, Ekonomicheskaia shkola, 1, $524 \mathrm{p}$.

20 Ekonomicheskii analiz normativnykh aktov [Economic analysis of regulatory acts] (2001). Edited by Tambovtsev, V.L., Ekonomicheskii fakul'tet MGU, TEIS, 408 p.

21 Elster, J. (1989). Social Norms and Economic Theory. In The Journal of Economic Perspectives, 4 (3), 89-117.

22 Tambovtsev, V.L. (2005). Pravo i ekonomicheskaia teoriia [Law and economic theory]. Moscow, INFRA-M, 224 p, $32-41$.

23 Ekonomicheskii analiz normativnykh aktov [Economic analysis of regulatory acts] (2001). Edited by Tambovtsev, V.L., Ekonomicheskii fakul'tet MGU, TEIS, $408 \mathrm{p}$.

24 Tambovtsev, V.L. (2011). Teorii institutsional 'nykh izmenenii [Theory of institutional changes], Moscow, INFRA-M, 154 p., 20.

25 Bukharova, E.B., Ferova, I.S. et al. (2011). Otsenka strategicheskoi konkurentosposobnosti innovatsionnogo potentsiala Krasnoiarskogo kraia $\mathrm{v}$ kontekste mirovykh trendov innovatsionnogo tekhnologicheskogo razvitiia [Evaluation of the strategic competitiveness of the innovative potential of the Kransoyarsk Krai in the context of world trends of innovative technological development]. Monograph, Krasnoyarsk, Siberian Federal University, 424 p.

26 Bukharova, E.B., Bezgachev, V.G. et al. (2009). Regional'naia sotsial'no-ekonomicheskaia sistema: territorial'noe planirovanie i upravlenie razvitiem (na primere Krasnoiarskogo kraia) [Regional socio-economic system: territorial planning and development management (on the example of the Krasnoyarsk Krai)]. Monograph, Krasnoyarsk, Siberian Federal University, 198 p.

27 Pyzhov, I.S., Rutskiy, V.N., Tanenkova, E.N., Ustyugova, N.V. (2012). A Study of the Institutional Environment Through Economic Analysis of Regulations on the Example of the Infrastructure for Population Living Conditions. Journal of Siberian Federal University. Humanities \& Social Sciences, 5(10), 1419-1427.

28 Pyzhev I.S., RutskiyV.N., Goryachev V.P. 02011). Infrastructure for Population Living Conditions in the Context of Qualitative Economic Growth. Journal of Siberian Federal University. Humanities \& Social Sciences, 4, 12.

29 Ibid.

\section{References}

Afontsev, S.A. (2010). Politicheskie rynki i ekonomicheskaia politika [Political markets and economic policy], Moscow, KomKniga, 384 p.

Alchian, A. (1950). Uncertainty, evolution and economic theory, In Journal of political economy, 58(3), 211-221.

Bukharova, E.B., Ferova, I.S. et al. (2011). Otsenka strategicheskoi konkurentosposobnosti innovatsionnogo potentsiala Krasnoiarskogo kraia $\mathrm{v}$ kontekste mirovykh trendov innovatsionnogo tekhnologicheskogo razvitiia [Evaluation of the strategic competitiveness of the innovative potential of the Kransoyarsk Krai in the context of world trends of innovative technological development]. Monograph, Krasnoyarsk, Siberian Federal University, 424 p.

Bukharova, E.B., Bezgachev, V.G. et al. (2009). Regional'naia sotsial'no-ekonomicheskaia sistema: territorial'noe planirovanie i upravlenie razvitiem (na primere Krasnoiarskogo kraia) [Regional socio-economic system: territorial planning and development management (on the example of the Krasnoyarsk Krai)]. Monograph, Krasnoyarsk, Siberian Federal University, 198 p.

Coase, R. (2007). Firma, rynok i pravo [The Firme, the Market and the Law], Moscow, Novoe izdatel'stvo, 224 p., 22.

Commons, J.R. (1931). Institutional economics, In American Economic Review, 21, 648-657.

Eggertsson, T. (2001). Ekonomicheskoe povedenie i instituty [Economic behaviour and institutions], Moscow: Delo, 408 p.

Ekonomicheskii analiz normativnykh aktov [Economic analysis of regulatory acts] (2001). Edited by Tambovtsev, V.L., Ekonomicheskii fakul'tet MGU, TEIS, 408 p. 
Elster, J. (1989). Social Norms and Economic Theory. In The Journal of Economic Perspectives, 4 (3), 89-117.

Hayek, F.A. (1992). Pagubnaia samonadeiannost'. Oshibki sotsializma [The Fatal Conceit: The Errors of Socialism], Moscow, Publishing House Novosti, 304 p.

Hodgson, G.M.(2003). Ekonomicheskaia teoriia i instituty: manifest sovremennoi institutsional'noi ekonomicheskoi teorii [Economic Theory and Institutions: a manifesto for a modern institutional economics], Moscow, Delo. 464 p, 202.

Kirdina, S.G. (2000). Institutsional'nye matritsy i razvitie Rossii [The institutional matrices and the development of Russia], Moscow: TEIS, $213 \mathrm{p}$.

Kleiner, G.B. (2004). Evoliutsiia institutsional'nykh system [The evolution of the institutional systems]. Moscow, Nauka, $240 \mathrm{p}$.

Levin, S.N. (2007). Formirovanie konstitutsionnykh pravil v ekonomike Rossii [Formation of the constitutional rules in the Russian economy]. Kemerovo, Kuzbassvuzizdat, 263 p.

Nelson, R.R., Winter, S.J.(2002). Evoliutsionnaia teoriia ekonomicheskikh izmenenii [Evolutionary Theory of Economic Change]. Moscow, Delo, 536 p, 142.

North, D. (1997). Institutsional'nye izmeneniia: ramki analiza [Institutional Changes: Analysis framework]. In Voprosy ekonomiki [The economy issues]. 3, 6-17.

Pejovich, S. (1996). The market for institution versus the strong hand of the state: the case of Eastern Europe. Economic Institutions, Market and Competition, B. Dallago and L. Mittone (eds), Cheltenham, 111-126.

Posner, R.A. (2004). Ekonomicheskii analiz prava [Economic Analysis of Law], translated from English. Saint Petersburg, Ekonomicheskaia shkola, 1, 524 p.

Polterovich, V.M. (2007). Elementy teorii reform [Elements of the reform theory]. Moscow, ZAO Publishing House Ekonomika, 447 p, 87-130.

Pyzhev I.S., Rutskiy, V.N., Goryachev, V.P. (2011). Infrastructure for Population Living Conditions in the Context of Qualitative Economic Growth. Journal of Siberian Federal University. Humanities \& Social Sciences, 4, 12.

Pyzhov, I.S., Rutskiy, V.N., Tanenkova, E.N., Ustyugova, N.V. (2012). A Study of the Institutional Environment through Economic Analysis of Regulations on the Example of the Infrastructure for Population Living Conditions. Journal of Siberian Federal University. Humanities \& Social Sciences, 5(10),1419-1427.

Pyzhev, I.S., Rutskiy, V.N. (2011). Institutsional'nyi podkhod k issledovaniiu infrastruktury zhiznedeiatel'nosti naseleniia makroekonomicheskogo urovmia [Institutional approach to the study of the infrastructure of the population's living conditions at the macroeconomic level]. In Nauchnye trusy DonNTU. Seriia: ekonomicheskaia [Scientific works of Donetsk National Technical University. Series: Economics], 40-2, 232-237.

Sapir, G.A. (2001). K ekonomicheskoi teorii neodnorodnykh system: opyt issledovaniia detsentralizovannoi ekonomiki [On the economic theory of non-uniform systems: research experience of the decentralized economy], Moscow, Higher School of Economics, 248 p, 171.

Simon, H.A. (2000). Teoriia priniatiia reshenii [Theory of decision-making]. In Vekhi ekonomicheskoi mysli. Teoriia firmy [Milestones of economic thought. Theory of the firm], 2. Ed. Gal'perin, V.M., St. Petersburg, School of Economics, 54-72. 
Tambovtsev, V.L. (2001). Institutsional'nyi rynok kak mekhanizm institutsional'nykh izmenenii [The institutional market as a mechanism for institutional changes]. In Obshchestvennye nauki $i$ sovremennost' [Social Sciences and Modernity], 5, 25-38.

Tambovtsev, V.L. (2005). Pravo i ekonomicheskaia teoriia [Law and economic theory]. Moscow, INFRA-M, 224 p, 32-41.

Tambovtsev, V.L. (2011). Teorii institutsional'nykh izmenenii [Theory of institutional changes], Moscow, INFRA-M, 154 p., 20.

Vol'chik, V.V. (2009). Komplementarnost' i ierarkhiia institutov v ramkakh khoziaistvennogo poriadka [Complementarity and hierarchy of institutions within the economic order]. Scientific works of Donetsk National Technical University, Series: Economics, 37-1, 35-41.

\title{
Институциональный анализ системы \\ публичных взаимодействий \\ в экономике региона по обеспечению \\ инфраструктуры жизнедеятельности \\ и качества жизни населения
}

\author{
В.Н. Руцкий \\ Сибирский федеральный университет \\ Россия, 660041, Красноярск, пр. Свободный, 79
}

Статья анализирует институциональную систему публичных взаимодействий населения региона и органов государственной власти и управления как систему обеспечения инфраструктуры жизнедеятельности населения региона в ходе качественного роста экономи$\kappa и$. Исследование опирается на метод экономического анализа нормативных актов как один из основных инструментов исследования, который модифицируется на основе сочетания неоинституциионального и системно-воспроизводственного подходов. Автор выявляет тенденции соответствующих институцииональных изменений в системе публичных взаимодействий в экономике региона на примере ряда первичных отраслей инфраструктуры - транспортного и градостроительного комплексов Красноярского края. Предложень необходимые направления соответствующего публичного институционального проектирования в регионе.

Ключевые слова: система публичных взаимодействий в экономике, инфраструктура жизнедеятельности населения, инфраструктурные блага, качественный экономический рост, экономический анализ нормативных актов, институциональный анализ.

Статья подготовлена при поддержке КГАУ «Красноярский краевой фонд поддержки научной и научно-технической деятельности» в рамках выполнения гранта, предоставленного Сибирскому федеральному университету за 2016 год, на тему: «Методологические подходы к оченке и формированию структурной политики воспроизводства человеческого капитала для обеспечения стратегии устойчивого развития территорий Красноярского края в условиях диверсификачии и технологической модернизачии экономики».

Научная спечиальность: 08.00.00 - экономические науки, 24.00.00 - культурология. 